\title{
Who Owns REDD+? Carbon Markets, Carbon Rights and Entitlements to REDD+ Finance
}

\author{
Charlotte Streck $1,2, *$ (D) \\ 1 Climate Focus, Schwedter Strasse 253, 10119 Berlin, Germany \\ 2 Department of International Politics, University of Potsdam, Am neuen Palais 10, 14496 Potsdam, Germany
}

Received: 12 July 2020; Accepted: 28 August 2020; Published: 1 September 2020

\begin{abstract}
The question of who is entitled to benefit from transactions under the United Nations framework to reduce emissions from deforestation and forest degradation (REDD+) remains one of the most controversial issues surrounding cooperative efforts to reduce deforestation in developing countries. REDD+ has been conceived as an international framework to encourage voluntary efforts in developing countries to reduce greenhouse gas emissions and enhance carbon removals from forest activities. It was designed as an international framework under the United Nations Framework Convention on Climate Change (UNFCCC) to enable the generation of emission reductions and removals (ERRs) at the national—and, provisionally, the subnational-level and is, thus, primarily a creature of international law. However, in defining forest carbon ERRs, the international framework competes with national emission trading systems and domestic REDD+ legislation as well as private standards that define units traded on the voluntary carbon market. As results-based and carbon market systems emerge, the question remains: Who can claim participation in REDD+ and voluntary carbon market projects? The existence of different international, national and private standards that value ERRs poses a challenge to countries that participate in REDD+ as well as to communities and private actors participating in voluntary carbon market projects. This paper seeks to clarify the nature and limitation of rights pertaining to REDD+ market transactions. It also links the notion of carbon rights to both carbon markets and government's decision on benefit sharing. Applying a legal lens, this paper helps to understand the various claims and underlying rights to participate in REDD+ transactions and addresses ambiguities that can lead to conflict around REDD+ implementation. The definition of carbon rights and the legal nature of carbon credits depend on local law and differ between countries. However, by categorizing carbon rights, the paper summarizes several legal considerations that are relevant for regulating REDD+ and sharing the financial benefits of transacting ERRs.
\end{abstract}

Keywords: REDD+; avoided deforestation; voluntary carbon markets; emissions trading; carbon rights; benefit sharing

\section{Introduction: Markets and Entitlement to REDD+ Benefits}

Tropical forest countries that engage in efforts to reduce greenhouse gas (GHG) emissions from deforestation and forest degradation and participate in the international framework on REDD+ (reduced emissions from deforestation and forest degradation and the role of conservation of forest carbon stocks, the sustainable management of forests and the enhancement of forest carbon stock-together REDD+ or REDD-plus) must put in place policies and incentives to address drivers of deforestation while safeguarding the rights of indigenous peoples and vulnerable communities. They must decide on how to allocate financial and non-financial benefits from the implementation of REDD+ to various stakeholders and policies [1-7]. Claims to participate in REDD+ are often based on the concept of 'carbon rights', and clear and uncontested carbon rights are often a condition for donor funding. 
For example, the World Bank's Forest Carbon Partnership Facility requires applicants for funds to clarify "the status of rights to carbon and relevant lands to establish a basis for successful implementation of the ER Program" [8] (Section 5.2, Indicator 30.1).

Relevant to the discussion of benefit sharing and carbon rights are efforts to link REDD+ to carbon markets. This link is being made in one of two ways: either by embedding avoided deforestation (AD) projects into public REDD+ programs—at the national or subnational level—or by making said programs themselves meet the standards of carbon markets by creating a fungible currency based on forest-related emission reductions and removals (ERRs). While such programs remain scarce, an increasing number of tropical forest countries have developed or are in the process of developing REDD+ strategies. In the meantime, a vibrant voluntary market dominated by private interests has seen a sharp increase in demand for AD offset credits over the last years [9]. This interest is further fueled by the possibility of including REDD+ or AD offsets as eligible compliance instrument under the International Civil Aviation Organizations (ICAO)'s Carbon Offsetting and Reduction Scheme for International Aviation (CORSIA) [10].

A great deal of insecurity and confusion has been introduced by the confluence of these contested topics: REDD+ benefit sharing, carbon rights and tradable carbon credits. As a result, the ownership of ERRs, a legitimate claim to REDD+ payments, and the respective underlying legal, political or ethical basis of these claims has been called into question. Public and private investors and other market actors are confronted with the challenge of identifying the holders of carbon rights, which often involves dissecting several layers of overlapping claims. The legal scholarship around REDD+ and forest carbon rights (e.g., [11-14]) remains incipient and scattered and, so far, offers limited help.

The objective of this paper is to organize and categorize the legal concepts that inform the debate on carbon rights and tradable carbon credits. By describing the rights relevant to participating in REDD+ and AD projects, the paper identifies the legal principles that inform REDD+ across all countries and provides examples on how these principles translate into REDD+ implementation. Ultimately, the definition of carbon rights and the legal nature of carbon credits depend on local laws and circumstances that differ between countries. However, there are a number of legal considerations that apply more generally, and certain underlying concepts are relevant for the understanding of REDD+ across different geographies.

\section{Method}

This paper contributes to the academic debate on REDD+ in the form of a legal essay on the nature of carbon units, ERRs and forest carbon rights. It applies the methodology of comparative legal research to analyze the genesis, application and reconstruction of the commoditization of forest carbon in the context of results-based payments and carbon markets. To date, there is limited legal analysis on carbon markets specific to forests. Existing literature has focused on the notion of 'carbon rights' (e.g., [11,12,14]), a concept that is frequently used and poorly defined. Carbon rights lack clear legal taxonomy, and there is limited legal scholarship around these rights. Instead, carbon rights occupy a particular legal-ethical dimension of REDD+ by identifying those that ought to benefit from REDD+.

On the basis of a literature review of the characterizations of carbon units, this paper analyzes the concept of carbon rights in different tropical forest countries' legislation and their implications for carbon pricing instruments. The comparison of carbon-rights legislation in different countries allows conclusions to be drawn on the implementation of REDD+ in different national contexts. Table 1 provides an overview of how relevant terms are used in the context of the present analysis.

The paper is structured as follows: Section 3 that follows provides a summary of the international context in which forest carbon transactions take place, introducing REDD+ and describing how the international framework intersects with voluntary carbon markets. Section 4 discusses the basic methodological requirements for creating tradable forest carbon credits. Section 5 analyzes the concept of carbon rights and land or activity-based claims to REDD+ payments, including the links to forest tenure. Section 6 provides an overview over the different regulatory levels that interact in the 
implementation of REDD+ and the carbon units issued at each level and their links to carbon rights. Section 7 concludes.

Table 1. Definitions.

\begin{tabular}{|c|c|}
\hline Term & Definition \\
\hline Emission reductions and removal, ERR & $\begin{array}{l}\text { An ERR refers to a reduction in GHG emissions and increase of carbon } \\
\text { absorption by biologic sinks calculated against a reference scenario and } \\
\text { monitored using standardized measurement, verification and reporting } \\
\text { (MRV) rules. }\end{array}$ \\
\hline Carbon unit & $\begin{array}{l}\text { A carbon unit refers to any issued, tradable and traceable instrument } \\
\text { representing an ERR (offset credit) or a permit to pollute (carbon } \\
\text { allowance). }\end{array}$ \\
\hline Offset credit & $\begin{array}{l}\text { An offset credit refers to an ERR that has been measured and accounted } \\
\text { for under a baseline-and-credit system, according to the rules of a } \\
\text { private or public carbon standard. Offset credits can be used to meet } \\
\text { voluntary or mandatory emission reduction obligations. }\end{array}$ \\
\hline Carbon allowance & $\begin{array}{l}\text { A carbon allowance is a right to emit a certain quantity of GHG } \\
\text { emissions in the context of a cap-and-trade system. }\end{array}$ \\
\hline Carbon rights & $\begin{array}{l}\text { Carbon rights (usually used in the plural form) refer to a justified claim } \\
\text { that there is a benefit from reduced GHG emissions and/or sequestered } \\
\text { carbon. The justification can be based on an activity that leads to forest } \\
\text { conservation or an asset, such as the title or management right to land } \\
\text { that enables forest conservation. }\end{array}$ \\
\hline Voluntary vs. compliance credits & $\begin{array}{l}\text { Compliance carbon credits are recognized to satisfy an emission } \\
\text { reduction obligation under a regulated emissions trading system. } \\
\text { Voluntary carbon credits are used to meet voluntary, self-set emission } \\
\text { targets. }\end{array}$ \\
\hline Avoided Deforestation (AD) vs. REDD+ & $\begin{array}{l}\text { AD refers to a project class under voluntary carbon market standards } \\
\text { that seeks to reduce emissions from avoiding deforestation while } \\
\text { REDD+ refers to a public sector program linked to the Warsaw } \\
\text { Framework for REDD+ as adopted under the UNFCCC. }\end{array}$ \\
\hline
\end{tabular}

\section{Context: REDD+ Results-Based Payments and Carbon Markets}

The framework for REDD+, a finance and incentive mechanism to conserve tropical forests, was adopted by the 19th session of the Conference of the Parties (COP) to the United Nations Framework Convention on Climate Change (UNFCCC) [15] in November 2013 in Warsaw, Poland [16]. The so-called Warsaw Framework for REDD+ (WFR) defines the international criteria for developing countries to reduce emissions and enhance forest carbon stocks and enables the provision of results-based climate finance payments in return for measured GHG reductions and removals. The WFR does not formulate rules for a market in ERRs but suggests that REDD+ could be a linked to market-based or other cooperation mechanisms, including market rules defined under Article 6 of the Paris Agreement. The WFR decision explicitly raises the possibility of "any further specific modalities for verification consistent with any relevant decision of the Conference of the Parties" [17].

Based on the WFR, nearly USD 4.7 billion have been pledged by governments for REDD+ results-based payments since 2010 [18]. This approach has been piloted by the Forest Carbon Partnership Facility (FCPF) and the BioCarbon Fund/Initiative for Sustainable Forest Landscapes administered by the World Bank, as well as bilateral programs such as Norway's International Climate and Forest Initiative and Germany's REDD Early Movers Program. These programs require a tracking of ERRs and assurances that no double counting or double selling has taken place. However, they do not require the generation of tradable units or transfer of title to ERRs. The FCPF is an exception as it requires the transfer of title to ERRs calculated and verified according to the Facility's methodological framework [19].

While current REDD+ transactions do not meet carbon-market standards, additional criteria (such as the establishment of registries, verification rules and more stringent rules for ERR measurement and accounting) could generate REDD+ offset credits of a quality required by carbon markets. Legislative 
action could allow for acceptance of ERRs for compliance purposes under, for instance, a domestic trading or carbon tax system. ERRs would become legally defined certificates-which are familiar from Kyoto Protocol's [20] Clean Development Mechanism (ERRs are issued under the CDM as Certified Emission Reductions) with characteristics that facilitate their transfer and tracking, as well as decisions regarding their acceptance as compliance instruments for offset.

Private carbon transactions already take place through a vibrant market in voluntary offset credits. These credits are generated under private standards, such as Verra's Verified Carbon Standard (VCS) [21] or the new ART/Trees standard [22]. The VCS registers projects and larger jurisdictional programs; ART/Trees focuses on verifying ERRs at a jurisdictional and national scale. While the ART/Trees standard has yet to issue credits, the VCS had issued more than 188 million units for land-use ERRs by the end of March 2020 [9]. The issuance of Verified Carbon Units (VCUs) for agriculture, forestry and other land uses (AFOLU) has outpaced other project classes registered under the VCS since 2016. In 2019, AFOLU issuances represented 72\% of all VCU issuances.

Unless domestic law links voluntary carbon projects to domestic schemes or national REDD+ programs, credits issued under private standards are separate and independent from the WFR or results-based payments. In Colombia, for example, VCS AD offset credits are eligible to meet compliance obligations under the country's carbon tax system [23] (offset credits must be generated in Colombia after 1 January 2010 and certified under an accredited carbon standard). While voluntary projects as an expression of non-state climate efforts are independent from national climate efforts, they nevertheless generate ERRs that contribute to a country's Nationally Determined Contribution (NDC) under the Paris Agreement.

Once the negotiations on voluntary cooperation and carbon markets under the Paris Agreement [24] are completed, REDD+ offsets may also be transferred under Article 6.2 or 6.4 of the Paris Agreement, provided REDD+ ERRs are considered eligible. In such a case, any international REDD+ ERR transfers must be supported by adjustments in NDC accounting, accounting both in the transferring country - where the corresponding amounts must be subtracted - and in the acquiring country, where the corresponding amounts must be added to the NDC. Such 'corresponding adjustments' are made to avoid of double counting [25] (paragraph 36).

\section{Carbon Markets: Creating Currency}

To the extent that REDD+ will be linked to carbon markets, it must create a uniform 'currency' that can be used to meet regulatory or voluntary mitigation obligations. Carbon markets' defining principle is the conversion of either a right to pollute or, as in the case of AD and REDD+, a measured ERR into a uniform, tradable unit. The allocation of a right to pollute defines the functioning of a regulated cap-and-trade system, such as the European Emissions Trading System (EU ETS) [26] or the California Cap and Trade System [27]. Offset credits are calculated against a baseline or reference emissions level under the rules of a compliance or voluntary standard, such as the CDM or the VCS. Where a cap-and-trade system recognizes offset credits, such credits become rights to pollute that are equivalent to allowances allocated under a cap-and-trade system.

The creation of a tradable carbon currency faces ethical, methodological and accounting barriers. The ethical dimension relates to concerns that public policy, at the international or national level, allocates rights to pollute and assigns "property interests in the sky" [28]. The concern is that the commoditization of pollution puts richer countries and communities at an advantage and creates an abuse in a global common that the state has a responsibility to protect. Deeper concern about the ability of market incentives to produce equitable and better ecological outcomes has led and continues to lead those critical of a neoliberal logic within the UNFCCC and national governments to prefer regulatory over market-based measures [29-33], even though the number of uncompromising market-critical environmentalists has decreased in the last two decades.

Establishing fungibility of allowances and offset credits means identifying and quantifying the 'sameness' among a wide range of activities [34]. This is comparatively easy in the case of cap-and-trade 
systems: A regulator defines an emissions cap that is below business-as-usual emissions and splits the total amount of the cap into allowances, each permitting emission of a certain quantity-generally one ton- of GHG emissions. Entities must match their emissions with allowances, acquiring more where needed and selling surplus where possible. Allowances are transferable rights to pollute that come into existence through an act of legislation that ensures a harmonized and fungible unit. However, only a few cap-and-trade systems cover the land sector, with the New Zealand emission trading system (NZ ETS) being a significant exception [35]. Under the NZ ETS, landowners can apply for 'New Zealand units' for forests that they commit to conserve, and forest owners must surrender New Zealand units to gain the right to deforest [36,37]. In the European Union (EU), the development of a monitoring system that would subject farms, forest owners and other land holdings to monitoring and reporting processes comparable to those for industry and energy installations is considered impractical [38]. The EU Commission argued that with respect to the EU ETS, it would be impossible to guarantee the compatibility and consistency of national accounting and reporting systems and to sustain the related costs [39]. Similarly, land use, land-use change and forestry (LULUCF) emissions were not included in the emission caps of developed countries under the Kyoto Protocol. Instead, they could be used-as offsets-to meet the emission limitation targets of developed countries [20].

Creating a fungible currency is challenging for offset credits that result from very heterogenous land use and forest activities. Each credit is created through a unique process that involves setting a baseline or reference emissions level, including a counterfactual emission scenario against which emission reductions (through conservation) and removals (through an increase of carbon sequestration) are measured. Such offset systems establish financial incentives to invest in emission reducing and removal enhancing activities outside of an established GHG emissions cap. Participation is, other than in the case of cap-and-trade systems, typically voluntary. Baseline-and-credit systems have the potential to drive a wide range of activities that reduce deforestation and increase forest cover. However, the establishment of emission reference scenarios and the creation of credible, permanent, and additional offset credits is complex [40], and ERRs are never made quite the same across and within different methodologies and standards.

REDD+ ERRs are accounted for against forest reference emissions levels using the logic of a baseline-and-credit system. Most tropical countries include the land sector in their NDCs, although it is not always clear which elements nor how land-based activities are accounted for. To date, there is no consistency across communicated forest reference emissions levels, NDCs, national communications and Biennial Update Reports (Biennial Update Reports contain updates from developing country GHG inventories, including a national inventory report and information on mitigation actions, needs and support received [41]), in part because of competing measurement and reporting systems. This leads to various overlaps in accounting and measurement, reporting and verification (MRV) systems. This situation is further complicated by competing REDD+ standards for results-based or market-based systems, such as the FCPF or the Green Climate Fund on one hand and the VCS or Trees/ART on the other, all with different rules and assumptions. This cacophony of national or jurisdictional measurement systems leads to a similarly confusing number of different types of ERRs, stemming from results-based payment, jurisdictional and project-based market systems for different purposes, driven by diverging underlying assumptions and resulting credits of widely different quality. Tropical forest countries have also found that generating and monetizing ERRs from REDD+ is much more challenging than the early narratives suggested (e.g., for Central Africa [42] and for Indonesia [43]).

There is also a risk of double counting climate benefits among overlapping claims for ERRs from systems that differ in the way they establish reference emissions levels in the scope of covered activities and details on definitions and MRV. This is particularly salient where different compliance systems claim overlapping units, such as conflicting CORSIA claims or conflicts between CORSIA, Article 6 Paris Agreement transactions and, potentially, units used for compliance under national offset systems. To safeguard the integrity of the Paris Agreement, it is further essential to ensure that ERRs are only accounted for under one NDC. As long as the voluntary market only supplies 
credits that support voluntary corporate sustainability claims, the overlap is limited. However, where voluntary credits are eligible to meet, for example, CORSIA or Article 6 requirements, they also need to manage the risk of double counting. To harmonize the various levels of carbon accounting, REDD+ projects can be 'nested' in national REDD+ programs [40,44-47]. Such nested REDD+ systems can help to ensure the environmental robustness of AD projects through coordinated rules for the establishment of reference emissions levels, but they also allow REDD+ projects be potential beneficiaries of results-based payments under the WFR $[40,45,46]$. Nesting has legal consequences since ERRs of different measurement and nature are converted to linked and eventually potentially fungible units: ERRs measured against project baselines established under voluntary standards and ERRs measured in the context of the WFR. While nesting helps to harmonize MRV systems and ERRs, the credibility of these systems hinges on the environmental integrity of the overarching national REDD+ accounting. Many reference emissions levels that tropical countries have submitted to the UNFCCC consider political developments (e.g., future development prospects or global deforestation rates [48]) to increase the number of potential ERRs [49-51]. These assumptions are not necessarily consistent with a conservative projection of deforestation.

Therefore, standards are essential for the smooth functioning of a market as they relate to measuring and accounting for emissions as well as consistent accounting for allowances and offset credits. While existing carbon markets have made much progress in the harmonization of rules, development and improvement of methodologies, and classification of various emission rights, it remains challenging to create functioning markets around comparable and fungible carbon assets.

\section{The Underlying Claim: Carbon Rights}

Given the importance of retaining clear standards and integrity in the carbon markets, tradable carbon credits must be distinguished from 'carbon rights', understood to be "the right to benefit from sequestered carbon and/or reduced greenhouse gas emissions" [12]. While legal constructs—such as land or tree ownership, customary or ancestral rights or the ability to perform an ecosystem service-are used to create a link from a carbon right to a carbon credit, they are regularly calibrated against notions of equity and fairness in the discussion of carbon rights and the ensuing benefit-sharing decisions.

Establishing forest carbon rights can lead to a claim to ERRs, and from there, to resulting offset credits as well as participation in REDD+ payments. The establishment of carbon rights is also a common requirement to access results-based finance (see, for example, the FCPF methodological framework [8] (Section 5.2)). The deeper sense of entitlement that comes with carbon rights makes them a decisive and contested notion in REDD+ systems, where many entities (individual or community landowners or managers, investors, project developers and public entities at various levels of governance) are involved in forest conservation activities.

Carbon rights can flow from either the ownership of the asset or the control of the activity that lead to a reduction in deforestation or an enhancement in forest carbon stocks:

a. The control of the asset refers to the carbon sink (the actual biomass) or the land that is undergoing conservation or restoration activities. As they relate to land, rights can imply full ownership, usufruct or management rights, under statuary, customary or traditional legal systems. There may be access rights that concern the right to passage or entry to an area, while withdrawal rights allow holders to enjoy the economic benefit of an area (e.g., to catch fish, collect firewood, appropriate water). Users with management rights have the right to establish the rules and sanctions under which forests can be managed (e.g., commercial or community management concessions) [14]. These rights can be transferable or inalienable, they can be subject to inherence or linked to a particular person or entity.

b. The control of the activity refers to the environmental service that the stewards of the forest or individual trees provide and that leads to a reduction of deforestation or additional tree planting. The activity can be controlled by a defined number of individuals, a community, a municipality or government agency. Project developers or investors often claim a secondary, transferred set of carbon rights for their services, financing and monetizing the ERRs flowing from a project or program. 
In the case of REDD+ projects, there are usually several entities that may cooperate in providing an environmental service. In the case of jurisdictional or national REDD+, the number of actors is often innumerable.

It is essential to recognize these two aspects of REDD+ to appropriately involve land custodians and those that address drivers of deforestation as actors and beneficiaries of national and international REDD+ and voluntary AD investments. This reflects the fact that resources and action must come together to achieve conservation.

\subsection{The Land Link: Carbon Rights and Forest Tenure}

How a country interprets and assigns carbon rights is closely related to the national forest tenure system. In many developing countries, forest resources are deemed to be the property of the state, which affords countries wide latitude to assert rights to some and deny others-particularly when new economic opportunities surface [12]. For example, the Democratic Republic of Congo passed a 'Homologation Decree' in 2018, which asserts that the national government as the national forest owner has the primary right to all carbon units. These can be transferred to private project developers through a "certificate d'homologation" [52]. In similar fashion, Mozambique considers all forest carbon rights to reside with the national government, though they can be transferred to project developers [53]. Madagascar goes a step further, proposing in a draft REDD+ decree that the government owns all ERRs generated by REDD+ activities and holds the exclusive right to commercialize such rights [54]. In Vietnam, the Law on Environmental Protection clarifies that any buying, selling and transferring of rights related to GHGs shall be approved by the prime minister, which complicates the development of private AD projects [55]. In Ecuador, the constitution establishes that all rights to ecosystem services belong to the state [56]. It also grants indigenous communities rights over more than half of the country's remaining forest land. However, this does not encompass the right to engage in carbon transactions. Environmental services are not an object of appropriation and, therefore, it is not possible to establish an ownership relationship between an entity or person and an environmental service.

The decision to claim all forest carbon rights for the state runs into legal problems in countries with customary, traditional or statutory land rights that may conflict with a decision to consolidate all forest carbon rights with the government. While the ownership of land and forests includes the right to benefit from its fruits, private and community landowners will argue that these fruits include benefitting from ERRs and REDD+. The monopolistic claim of forest carbon rights by the government is generally hard to defend in countries with strong community and private property rights. A government claim to all forest carbon rights could be interpreted by courts as taking property for which governments and the original right holders would need to be duly compensated.

Consequently, countries with land systems that allow private and community forest ownership seek to differentiate between the rights pertaining to state forest resources and those resting with individuals or communities. In Chile, the claims to REDD+ benefits follow land ownership [57]. The government recognizes the decision of landholders to participate in any AD project or program involving compensation in exchange for ERRs, as well as the right to freely carry out any activity on one's land, including conservation and reforestation activities within the limits of the law. Owners may also generate ERRs and trade them in voluntary or compliance carbon markets. In the latter case, national authorities ensure that owners report the sale of ERRs so that these may be deducted from the national count and, therefore, avoid double entry. Meanwhile, Guatemala's Climate Change Law clarifies that "the rights, title and negotiations of the carbon emission reduction units" [58] belong to project developers and those with a title to manage the land and, thus, opens the door for private carbon market projects. Peru regulates carbon rights through the legislation of ecosystem services and explicitly differentiates between asset holders and service providers. The contributors to environmental services are those that (i) implement actions contributing to the conservation, recovery and sustainable use of the sources of the ecosystem service ('activity factor') and those that (ii) hold forest tenure or control forest resources ('tenure factor') [59]. Costa Rica also regulates carbon rights in the context of 
payment-for-ecosystem services (PES). The legal framework of Costa Rica establishes that individual or collective owners of land can receive benefits from the sale of ERRs. PES legislation is anchored in the strong recognition of private property rights reflected in the Constitution of Costa Rica [60].

Finally, Mexico recognizes the logical difference between claims to carbon sequestered and emissions avoided. Landowners hold carbon rights for sequestration activities while there are no private rights to GHG emissions reductions from avoided deforestation (which, per definition, is illegal in the country). Since it is not possible to claim a right on the avoidance of an illegal activity, emission reductions from REDD+ are owned by the government [61]. A convincing differentiation as activities that reduce pressure from forests have a much less direct link with the land on which trees are standing than do afforestation or reforestation projects. The removal of pressure from the land means diversion of an activity from the land to be conserved, while planting trees means direct engagement on the land. In the case of reduced deforestation, the claim to carbon rights is more likely to be represented as an environmental service of conservation than a right to sequestration. The right to benefit from REDD+ becomes more abstract since it may involve activities at significant distance from the forest frontier. This is why carbon rights also have a strong link to activities to be implemented, and it becomes more difficult to compare them to land easements (as proposed by Karsenty et al. [62]). See Table 2 for an overview of carbon rights in relation to different land tenure systems.

Table 2. Overview of carbon rights systems.

\begin{tabular}{ccc}
\hline Land Ownership & Carbon Rights & $\begin{array}{c}\text { Ability of Non-State Entities to } \\
\text { Engage in Carbon Offset Activities }\end{array}$ \\
\hline $\begin{array}{c}\text { All forest land is owned by the } \\
\text { government. }\end{array}$ & $\begin{array}{c}\text { Carbon rights follow the right to the land } \\
\text { and are owned by the state, but the right } \\
\text { to generate ERR can be transferred to } \\
\text { private entities. }\end{array}$ & $\begin{array}{c}\text { Carbon rights can be transferred to } \\
\text { private and public entities via } \\
\text { concession or license. }\end{array}$ \\
\hline Examples
\end{tabular}

Democratic Republic of Congo: The 1973 General Property Law (Law No. 73-021), as amended, provides for state ownership of all land, subject to rights of use granted under state concessions. However, much of the land is under customary ownership [63]. The government can authorize private projects, in which case it transfers the right to "réductions d'émissions congolaises (Urec)" to private project developers [52] (Art. 3).

Mozambique: All natural forest and wildlife resources are the property of the state [64] (Art. 109). However, the Land Law of 1997 establishes that individuals, communities and entities can obtain long-term or perpetual rights to land [65]. REDD+ ERRs are owned by the state [53] (Art. 6.1) and all credits are issued by the government. Private projects can receive a license to generate and market ERRs.

Vietnam: All forest land is owned by the state; however, private entities, including households, may be allocated or lease forest land for 50 years [66]. Private entities can develop REDD+ projects, however, projects must be approved by the Prime Minister [67].

\begin{tabular}{|c|c|c|}
\hline $\begin{array}{l}\text { State or diverse forest ownership } \\
\text { with weak private land titles. }\end{array}$ & $\begin{array}{l}\text { Carbon rights (e.g., Madagascar) or rights } \\
\text { to ecosystem services (e.g., Ecuador) are } \\
\text { centralized and managed at the level of } \\
\text { the national government. }\end{array}$ & $\begin{array}{l}\text { Private projects or transactions } \\
\text { involving ERRs are not permitted. }\end{array}$ \\
\hline \multicolumn{3}{|c|}{ Examples } \\
\hline \multicolumn{3}{|c|}{$\begin{array}{l}\text { Ecuador: Though almost all of Ecuador's forests are held by privates or communities, about half of these lands have } \\
\text { unresolved land tenure issues [68]. Indigenous peoples administer large parts of the forest land. However, all ecosystem } \\
\text { services, including the right to engage in carbon transactions, belong to the state. } \\
\text { Madagascar: All forests except for those on titled land are state property. In } 2019 \text {, in Madagascar only } 7 \% \text { of the land is } \\
\text { titled [69]. While the state is the owner of all forests, co-management between the state and local communities was enabled } \\
\text { by the } 1996 \text { Gestion Locale Sécurisée Law (Law No. 96-025). The government controls access to ERRs and it is not clear } \\
\text { whether the government will authorize private projects. }\end{array}$} \\
\hline $\begin{array}{l}\text { Diverse forest ownership with } \\
\text { community and private land titles. }\end{array}$ & $\begin{array}{l}\text { Carbon rights are regulated, and special } \\
\text { rules apply. }\end{array}$ & $\begin{array}{l}\text { Private entities are free to participate in } \\
\text { voluntary carbon market projects } \\
\text { subject to restrictions. }\end{array}$ \\
\hline
\end{tabular}


Table 2. Cont.

\begin{tabular}{|c|c|c|}
\hline \multicolumn{3}{|c|}{ Examples } \\
\hline \multicolumn{3}{|c|}{$\begin{array}{l}\text { Costa Rica: About half of Costa Rica's forests are privately owned [70]. The national PES system covers about } 20 \% \text { of the } \\
\text { national territory and facilitates the linkage of conservation and management of forest resources to socioeconomic } \\
\text { development [71]. Landowners hold rights to ERRs as part of their right to benefit from ecosystem services [72]. } \\
\text { Guatemala: In Guatemala, ownership of forests is linked to that of the land, except when the land title specifies otherwise. } \\
\text { Forests are located on state, municipal, communal and private lands and within protected areas. Private forests constitute } \\
\text { about } 38 \% \text { of total forest area, public forests constitute about thirty } 34 \% \text {, and the rest are community-managed forests [73]. } \\
\text { The Climate Change Law of Guatemala clarifies the right of private individuals and communities to engage in AD projects } \\
\text { and market ERRs. } \\
\text { Peru: Land laws in Peru are not consistent. The Constitution assigns natural resources to the state. Privately owned } \\
\text { categories of forest land include land held by Amazonian indigenous communities, Andean peasant communities, private } \\
\text { conservation areas and private agriculture plots [74]. About half of the land in Peru is titled. Peru considers REDD+ and AD } \\
\text { as ecosystem services and has provided detailed guidance on how private and community actors can benefit from providing } \\
\text { ecosystem services. A special resolution (RP-26-2014) regulates the commercialization of REDD+ in national parks. }\end{array}$} \\
\hline $\begin{array}{l}\text { Diverse forest ownership with } \\
\text { strong community and private } \\
\text { titles. }\end{array}$ & $\begin{array}{l}\text { No special regulation. Carbon rights } \\
\text { pertain to landholders. }\end{array}$ & $\begin{array}{c}\text { Private entities are free to participate in } \\
\text { voluntary carbon market projects within } \\
\text { the limits of the law regarding land use } \\
\text { and safeguards. }\end{array}$ \\
\hline \multicolumn{3}{|c|}{ Examples } \\
\hline \multicolumn{3}{|c|}{$\begin{array}{l}\text { Chile: Chile has a strong forest sector and allows private forest ownership [75]. The country has no dedicated legislation on } \\
\text { carbon rights in place but honors the rights of land and forest owners to participate in AD projects. } \\
\text { Mexico: Mexico has a sophisticated set of laws to regulate forest protection. Of the total forest surface, about } 70 \% \text { is } \\
\text { community property, } 26 \% \text { is private property (small-scale landowners), and the remaining } 4 \% \text { is government property [76]. } \\
\text { Applying general principles of law, Mexico differentiates between the rights to sequestered carbon (removals) and avoided } \\
\text { emissions from deforestation (which equal to the avoidance of an illegal activity). Only the former can be transacted by } \\
\text { private entities. The extent to which the government can or will participate in REDD+ ERR transactions is still under } \\
\text { consideration [77]. }\end{array}$} \\
\hline
\end{tabular}

It is important to note that establishing carbon rights can be challenging even where legal clarifications exist; in particular, where land titles are weak, contested or absent. Contestable land title, overlapping tenure regimes and land grabbing all lead to violence, illegality and marginal livelihoods across developing countries. Weak recognition of tenure rights, failure to respect the principle of free, prior and informed consent and growing demand for land have led to an increase in land conflicts and growing dangers for communities defending their land rights, including increased violence against forest defenders [78]. High concentrations of land ownership in Latin America as a result of colonial land policy further aggravates land conflicts $[79,80]$. In Africa, land conflicts are also fueled by land concentration, commercialization and deepening social differentiation among land-users [81,82]. This means that the question of who has the right to benefit from REDD+ often becomes a proxy for unsolved and contested rights to land, and with it, a pathway to opportunities and development. REDD+ also intersects with the historic marginalization of indigenous and forest communities and their long struggle to assert land and resource rights [78]. This requires careful considerations when deciding on claims to REDD+ and ancestral claims to participation may often be stronger than recently awarded land management rights.

\subsection{The Activity Link: Ecosystem Services and Investments}

Benefits to REDD+ are also claimed by those that achieve ERRs as well as by those that enable such achievement through finance, technology or training. The realization of ERRs depends on what legislation in Peru refers to as 'activity factor'. Carbon rights based on activity can be claimed by communities that protect and sustainably manage forests, local governments that administer conservation areas or land managers that sequester carbon through tree planting. Secondary contributors, such as investors or project developers, often require the transfer of the claim to ERRs in return for their contribution to AD.

Activity-based carbon rights can conflict with asset-based carbon rights, in particular, where the government holds the rights to the land and forest resources, and the AD activities are implemented by communities, individuals or private legal entities. In these cases, benefit-sharing arrangements 
must clarify and balance different rights. Where there are different overlapping claims to benefits that flow from sequestered carbon or reduced GHG emissions, local land and service agreements can help to avoid conflict over responsibilities and benefits in relation to REDD+ to secure rights. Rights can be clarified in community concessions issued by local or national governments (in the context of the GuateCarbon project, for example, the Government of Guatemala has issued 12 community forestry concessions to local communities. [83]). These arrangements must also acknowledge that marginalized communities are often pushed into the forest because of a lack of other development opportunities. For those communities, REDD+ should provide an opportunity to increase resilience and address poverty. A pro-poor equitable sharing of benefits also recognizes forest stewards who have been managing the forests sustainably, particularly indigenous communities [7].

In $\mathrm{AD}$ projects of the voluntary carbon market, contracts with local communities can divide the roles and responsibilities as well as the rights to benefit from payments associated with the commercialization of carbon rights via market or non-market transactions. In a market-based approach, offset credits represent a financial expression of carbon rights [62], and to avoid socially undesirable outcomes and disputes, contracts between parties must clarify who has the right to convert ERRs in carbon units.

\section{Layers of Rights and Units: Markets and REDD+}

The results-based logic of REDD+, as defined in the WFR, puts REDD+ in the regulatory proximity of carbon markets. The leap from results-based payments to market-based REDD+ is comparatively small. However, ERRs must meet requirements of uniformity in MRV and quality to ensure the creation of fungible, tradable carbon units. Such units are, at the same time, a highly esoteric legal concept and a potentially extremely valuable tradable commodity. Where allowances are allocated by governments, they often are considered as permits that express the authorization or entitlement to emit a certain amount of GHGs [84]. Offset credits are-independent from an allocating authority-issued under public ('compliance') or private ('voluntary') standards [85]. The CDM represents a compliance standard under public international law, while Australia's Carbon Farming Initiative [86] represents a compliance standard under local law. Colombia links offset credits generated by approved standards to its carbon tax system. Brazil is currently considering a market in tradable forest certificates that allows landowners to offset their restoration obligations by paying for maintaining native vegetation elsewhere [87]. This program holds significant potential [88], however, it comes in the context of a weakened Forest Code and its effectiveness remains to be seen. Similar systems could be implemented in other tropical forests in the future.

If issued by a private standard, such as Verra or the Gold Standard, a carbon credit does not embody any administrative authorization. It is a mere private, tradable certificate. An issued offset credit embodies a fungible interest in an ERR which, through its conversion into an offset credit, has become independent from a particular sequestration or land-related abatement activity [89]. Legally, the carbon offset entails the assurance that an abatement activity has met certain social and environmental criteria (safeguards and consultations) and reduced or sequestered an established quantity of GHG emissions. The credit gives the holder the right to claim the benefits of the ERR, for example, to meet carbon neutrality claims. The issued offset credit embodies the environmental value or service that led to the issuance of the credit.

In sum, in the context of REDD+, it is important to differentiate between the different levels of law making and standard setting: (1) REDD+ as international incentive mechanism applicable to state parties to the UNFCCC and the Paris Agreement; (2) national emission trading and offset systems as in New Zealand, Australia or Colombia; (3) laws that regulate REDD+ at the national level, (4) voluntary carbon markets governed by private standards and law; and (5) rights defined in and based on bilateral, private or public contracts. All five systems create different units applying their specific rules, as seen in Table 3. 
Table 3. Rights to carbon relevant to REDD+.

\begin{tabular}{|c|c|c|c|}
\hline Legal Source & Instrument & Carbon Unit & Comments \\
\hline International law & UNFCCC, Paris Agreement & $\begin{array}{l}\text { No defined legal } \\
\text { instruments, decisions } \\
\text { establish how to generate } \\
\text { ERRs that can be linked } \\
\text { to payments. }\end{array}$ & $\begin{array}{l}\text { Results-based payments link } \\
\text { payments to performance but do } \\
\text { not involve carbon trading. }\end{array}$ \\
\hline \multirow{2}{*}{$\begin{array}{l}\text { Supra-national and } \\
\text { national law }\end{array}$} & $\begin{array}{l}\text { EU ETS, NZ ETS, Colombian } \\
\text { ETS (under development, to } \\
\text { complement the national } \\
\text { carbon tax and offsetting } \\
\text { program) }\end{array}$ & $\begin{array}{l}\text { Regulated carbon units } \\
\text { in the form of allowances } \\
\text { and/or offset credits. }\end{array}$ & $\begin{array}{l}\text { ETS may accept offset credits that } \\
\text { meet defined criteria. Offset } \\
\text { credits "imported" in a } \\
\text { cap-and-trade system generally } \\
\text { become equivalent to allowances } \\
\text { as compliance instrument. }\end{array}$ \\
\hline & REDD+ or PES regulations & $\begin{array}{l}\text { No defined legal } \\
\text { instruments, regulation } \\
\text { establishes right to } \\
\text { payments or ERRs. }\end{array}$ & $\begin{array}{l}\text { Legislation concerned with } \\
\text { clarifying who can benefit from } \\
\text { REDD+. Regulation in the context } \\
\text { of PES systems, climate or forest } \\
\text { laws or dedicated REDD+ } \\
\text { legislation. }\end{array}$ \\
\hline Private law & Private carbon standards & $\begin{array}{l}\text { Voluntary offset credits } \\
\text { defined by private } \\
\text { standards. }\end{array}$ & $\begin{array}{l}\text { The VCS or the Gold Standard are } \\
\text { examples of standards that issue } \\
\text { tradable carbon credits. }\end{array}$ \\
\hline Private or public law & Contracts & $\begin{array}{l}\text { ERRs defined on the } \\
\text { basis of a contract. }\end{array}$ & $\begin{array}{l}\text { FCPF General Conditions defining } \\
\text { emission reductions; contracts can } \\
\text { also make references to voluntary } \\
\text { or regulated offset credits. }\end{array}$ \\
\hline
\end{tabular}

The overlapping international, national and private sources of law that determine REDD+ and AD pose a veritable challenge to countries. Many countries look to international and bilateral results-based payment programs to support their national REDD+ programs. They see the benefit of attracting private finance for REDD+ and voluntary AD projects. They also consider PES systems and emissions trading systems as part of the public policies that support a national RDD+ program. Units generated under the different systems differ in their reach and limitations, which can result in overlapping claims that may generate conflicts. A clear understanding of carbon rights and transparent regulation on who can benefit from national REDD+ can help to resolve and, even more importantly, avoid conflicts. Participants in private REDD+ projects also consider carbon rights and clarify responsibilities and benefits of land and resource holders and project participants in project agreements.

\section{Concluding Remarks}

Direct carbon market investments only constitute one-and, most likely, a transitionary—strategy towards reducing deforestation. Sustainable land and forest use depends on strong forest governance, including land tenure reform, land-use planning and the strengthening of law enforcement and forest institutions. While taking time to materialize, investments in law enforcement have been shown to pay off and ensure fair returns from investments in sustainable land management [90]. PES systems can complement and eventually replace voluntary AD projects passing on a results-based logic on larger segments of the populations and creating long-term incentives to safeguard forest resources. In the meantime, private $\mathrm{AD}$ projects may raise funds and protect critical ecosystems while results-based and other climate finance can support the transition towards stronger governance and long-term sustainability. In this process, the notion of carbon rights provides a valuable instrument to recognize the needs and rights of the stewards of existing forests as well as those that invest in conservation. REDD+ can only be realized if it increases the prosperity of forest-dependent, indigenous and local communities, smallholders and others that edge out a life at the forest frontier while also experiencing improved forest governance and having the support of strong political will. Legal standards and clear concepts can contribute to long-term sustainable forest landscapes. 
Funding: This research received no external funding.

Conflicts of Interest: The author declares no conflict of interest.

\section{References}

1. Wong, G.Y.; Luttrell, C.; Loft, L.; Yang, A.; Pham, T.T.; Naito, D.; Assembe-Mvondo, S.; Brockhaus, M. Narratives in REDD+ Benefit Sharing: Examining Evidence within and beyond the Forest Sector. Clim. Policy 2019, 19, 1038-1051. [CrossRef]

2. Transforming REDD+: Lessons and New Directions; Angelsen, A. (Ed.) Center for International Forestry Research: Bogor, Indonesia, 2018.

3. Andersson, K.P.; Smith, S.M.; Alston, L.J.; Duchelle, A.E.; Mwangi, E.; Larson, A.M.; de Sassi, C.; Sills, E.O.; Sunderlin, W.D.; Wong, G.Y. Wealth and the Distribution of Benefits from Tropical Forests: Implications for REDD+. Land Use Policy 2018, 72, 510-522. [CrossRef]

4. Duchelle, A.E.; Seymour, F.; Brockhaus, M.; Angelsen, A.; Larson, A.M.; Wong, G.Y.; Pham, T.T.; Martius, C. REDD+: Lessons from National and Subnational Implementation; World Resources Institute: Washington, DC, USA, 2018; p. 17.

5. Loft, L.; Pham, T.T.; Wong, G.Y.; Brockhaus, M.; Le, D.N.; Tjajadi, J.S.; Luttrell, C. Risks to REDD+: Potential Pitfalls for Policy Design and Implementation. Environ. Conserv. 2017, 44, 44-55. [CrossRef]

6. Loft, L.; Pham, T.T.; Luttrell, C. Lessons from Payments for Ecosystem Services for REDD+ Benefit-Sharing Mechanisms; Center for International Forestry Research (CIFOR): Bogor, Indonesia, 2014. [CrossRef]

7. Luttrell, C.; Loft, L.; Fernanda Gebara, M.; Kweka, D.; Brockhaus, M.; Angelsen, A.; Sunderlin, W. Who Should Benefit from REDD+? Rationales and Realities. Ecol. Soc. 2013, 18. [CrossRef]

8. Forest Carbon Partnership Facility. FCPF Carbon Fund, Methodological Framework; Version 3.0; World Bank: Washington, DC, USA, 2020.

9. Verified Carbon Standard. Data Insights April 2020. Available online: https://verra.org/datainsights/april2020/ (accessed on 1 August 2020).

10. Chagas, T.; Galt, H.; Lee, D.; Neeff, T.; Streck, C. Should Forest Carbon Credits Be Included in Offsetting Schemes Such as CORSIA? Climate Focus: Washington, DC, USA, 2019.

11. Streck, C. In the Market Current Developments in Carbon \& Climate Law: Forest Carbon Rights-Shedding Light on a Muddy Concept. CCLR 2015, 2015, 342-347.

12. Knox, A.; Vhugen, D.; Aguilar, S.; Peskett, L.; Miner, J. Forest Carbon Rights Guidebook: A Tool for Framing Legal Rights to Carbon Benefits Generated through REDD+ Programming; USAID: Washington, DC, USA, 2012.

13. Chapman, S.; Wilder, M.; Millar, I. Defining the Legal Elements of Benefit Sharing in the Context of REDD. CCLR 2014, 2014, 270-281.

14. Corbera, E.; Estrada, M.; May, P.; Navarro, G.; Pacheco, P. Rights to Land, Forests and Carbon in REDD+: Insights from Mexico, Brazil and Costa Rica. Forests 2011, 2, 301-342. [CrossRef]

15. United Nations. Framework Convention on Climate Change; United Nations Treaty Collection, 1771 UNTS 107: New York, NY, USA, 1994.

16. UNFCCC. Warsaw Framework for REDD-Plus; UNFCCC: Bonn, Germany, 2013; Decisions 9-15/CP19.

17. UNFCCC. Warsaw Framework for REDD-Plus, Modalities for Measuring, Reporting and Verifying; UNFCCC: Bonn, Germany, 2013; Decision 14/CP.19; Para. 15.

18. NYDF Assessment Partners. Goal 9: Reward Positive Results/New York Declaration on Forests; Goal Assessment Update; NYDF Assessment Partners: Washington, DC, USA, 2019; p. 9.

19. International Bank on Reconstruction and Development. General Conditions Applicable to Emission Reductions Payment Agreements; The Forest Carbon Partnership Facility; World Bank: Washington, DC, USA, November 2014; Available online: https://www.forestcarbonpartnership.org/erpa-general-conditions (accessed on 1 August 2020).

20. United Nations. The Kyoto Protocol to the United Nations Framework Convention on Climate Change; United Nations Treaty Collection, C.N.101.2004: New York, NY, USA, 1997.

21. Verified Carbon Standard. Available online: https://verra.org/project/vcs-program/ (accessed on 1 August 2020).

22. ART, Architecture for REDD+ Transactions. Available online: https://www.artredd.org (accessed on 1 August 2020). 
23. Government of Colombia. Reforma Tributaria Estructural. Ley 1819, 2016, Article 221.

24. United Nations. The Paris Agreement; United Nations Treaty Collection, C.N.63.2016: New York, NY, USA, 2016.

25. UNFCCC. Decision on the Paris Agreement; UNFCCC: Bonn, Germany, 2015; Decision 1/CP.21.

26. European Parliament and Council. Directive Establishing a Scheme for Greenhouse Gas Emission Allowance Trading within the Community and Amending Council Directive 96/61/EC; European Parliament and Council: Brussels, Belgium, 2003.

27. California Assembly. California Global Warming Solutions Act of 2006: Market-Based Compliance Mechanism; California Assembly: Sacramento, CA, USA, 2017.

28. Torres, G. Who Owns the Sky Past Garrison Lecture Reprints \& Addenda-Seventh Annual Lloyd, K. Garrison Lecture on Environmental Law. Pace Environ. Low Rev. 2001, 19, 515-574.

29. Blumm, M.C. Fallacies of Free Market Environmentalism. The Free Market Environmentalism: The Role of the Market in Environmental Protection Northwest School of Law at Lewis and Clark College-1991. Harv. J. Low Public Policy 1992, 15, 371-390.

30. Menell, P.S. Institutional Fantasylands: From Scientific Management to Free Market Environmentalism Free Market Environmentalism: The Role of the Market in Environmental Protection Northwest School of Law at Lewis and Clark College-1991. Harv. J. Low Public Policy 1992, 15, 489-510.

31. Newell, P.; Paterson, M. A Climate for Business: Global Warming, the State and Capital. Rev. Int. Political Econ. 1998, 5, 679-703. [CrossRef]

32. Newell, P.; Roberts, J.T. The Globalization and Environment Reader; John Wiley \& Sons: Hoboken, NJ, USA, 2016.

33. Ciplet, D.; Roberts, J.T. Climate Change and the Transition to Neoliberal Environmental Governance. Glob. Environ. Chang. 2017, 46, 148-156. [CrossRef]

34. MacKenzie, D. Making Things the Same: Gases, Emission Rights and the Politics of Carbon Markets. Account. Organ. Soc. 2009, 34, 440-455. [CrossRef]

35. Government of New Zealand. Climate Change Response (Emissions Trading) Amendment Act 2008; New Zealand Legislation: Wellington, New Zealand, 2008.

36. Leining, C.; Kerr, S.; Bruce-Brand, B. The New Zealand Emissions Trading Scheme: Critical Review and Future Outlook for Three Design Innovations. Clim. Policy 2020, 20, 246-264. [CrossRef]

37. Government of New Zealand. Deforesting Forest Land, Te Uru Rākau, Forestry New Zealand. Available online: https:/www.mpi.govt.nz/growing-and-harvesting/forestry/forestry-in-the-emissionstrading-scheme/deforesting-forest-land/ (accessed on 1 August 2020).

38. Savaresi, A.; Perugini, L. The Land Sector in the 2030 EU Climate Change Policy Framework: A Look At The Future. J. Eur. Environ. Plan. Law 2019, 16, 148-164. [CrossRef]

39. European Commission. Commission Staff Working Document, Impact Assessment on the Role of Land Use, Land Use Change and Forestry (LULUCF) in the EU's Climate Change Commitments; European Commission: Brussels, Belgium, 2012.

40. Chagas, T.; Streck, C.; Olander, J.; Seifert-Granzin, J.; O'Sullivan, R. Nested Approached to REDD+: An Overview of Issues and Options; Forest Trends, Climate Focus: Washington, DC, USA, 2011; p. 50.

41. UNFCCC. UNFCCC Biennial Update Reporting Guidelines for Parties Not Included in Annex I to the Convention; UNFCCC: Bonn, Germany, 2011; Decision 2/CP.17 Annex III.

42. Tsayem Demaze, M.; Sufo-Kankeu, R.; Sonwa, D.J. Analysing the Narrative and Promises of "Avoided Deforestation" Implementation in Central Africa. Available online: https://www.cifor.org/knowledge/ publication/7651/ (accessed on 1 August 2020).

43. Enrici, A.; Hubacek, K. A Crisis of Confidence: Stakeholder Experiences of REDD+ in Indonesia. Hum. Ecol. 2019, 47, 39-50. [CrossRef]

44. Angelsen, A.; Streck, C.; Peskett, L.; Brown, J.; Luttrell, C. What Is the Right Scale for REDD?: The Implications of National, Subnational and Nested Approaches; Center for International Forestry Research (CIFOR): Bogor, Indonesia, 2008. [CrossRef]

45. Pedroni, L.; Dutschke, M.; Streck, C.; Porrua, M.E. Creating Incentives for Avoiding Further Deforestation: The Nested Approach. Clim. Policy 2009, 9, 207-220. [CrossRef] 
46. Cortez, R.; Saines, R.; Griscom, B.; Martin, M.; de Deo, D.; Fishbein, G.; Kerkering, J.; Marsh, D. A Nested Approach to REDD+: Structuring Effective and Transparent Incentive Mechanisms for REDD+Implementation at Multiple Scales; The Nature Conservancy: Arlington County, VA, USA; Baker\&McKenzie: Chicago, IL, USA, 2010.

47. Gibbon, A.; Pearson, T.; Walker, S.; Andrasko, A. Planning Guide: Integrating REDD+ Accounting within Nested Approach; Lowering Emissions in Asia's Forests (LEAF); USAID: Washington, DC, USA, 2014.

48. Government of Guyana. The Reference Level for Guyana's REDD+ Program; Georgetown, Guyana, 2014.

49. Hargita, Y.; Günter, S.; Köthke, M. Brazil Submitted the First REDD+ Reference Level to the UNFCCC-Implications Regarding Climate Effectiveness and Cost-Efficiency. Land Use Policy 2016, 55, 340-347. [CrossRef]

50. Angelsen, A. REDD+ as Result-Based Aid: General Lessons and Bilateral Agreements of Norway. Rev. Dev. Econ. 2017, 21, 237-264. [CrossRef]

51. Mertz, O.; Grogan, K.; Pflugmacher, D.; Lestrelin, G.; Castella, J.-C.; Vongvisouk, T.; Hett, C.; Fensholt, R.; Sun, Z.; Berry, N.; et al. Uncertainty in Establishing Forest Reference Levels and Predicting Future Forest-Based Carbon Stocks for REDD+. J. Land Use Sci. 2018, 13, 1-15. [CrossRef]

52. Government of the Democratic Republic of Congo. Arrêté Ministériel Fixant La Procédure d'homologation Des Projets REDD+; Kinshasa, Congo, 2018.

53. Government of Mozambique. Regulamento Para Programas e Projectos Inerentes à Redução de Emissões Por Desmatamento e Degradação Florestal de Carbono (REDD+); Maputo, Mozambique, 2018.

54. Government of Madagascar. Draft Benefit Sharing Plan, ER Program Atiala Atsinanana; FCPF Benefit Sharing Plan Version 2.0; Antananarivo, Madagascar, 2020.

55. Sharma, S.; Shivakoti, G.; Thang, T.N.; Dung, N.T. Is Vietnam Legally Set for REDD+? In Redefining Diversity E Dynamics of Natural Resources Management in Asia; Elsevier: Amsterdam, The Netherlands, 2017; Volume 3, pp. 205-218. [CrossRef]

56. Government of Ecuador. Constitution of the Republic of Ecuador of 2008; Quito, Ecuador, 2008.

57. Government of Chile. Cambio Climático y Bosques: Regulación Jurídica Nacional e Internacional Desde Un Enfoque de REDD+ y Aplicado a La Estrategia Nacional de Cambio Climático y Recursos Vegetacionales (ENCCRV) (2017-2025) de Chile; Manual de Estudios; ENCCRV: Santiago, Chile, 2017.

58. Government of Guatemala. Ley Marco Para Regular La Reducción de La Vulnerabilidad, La Adaptación Obligatoria Ante Los Efectos Del Cambio Climático y La Mitigación de Gases de Efecto Invernadero; Guatemala City, Guatemala, 2013.

59. Government of Peru. Reglamento de La Ley No 30215, Ley de Mecanismos de Retribución Por Servicios Ecosistémicos; Vol. Decreto Supremo No 009-2016-MINAM; Lima, Peru, 2016.

60. Government of Cost Rica. Constitution of Costa Rica from 1949; San Jose, Costa Rica.

61. Felicani Robles, F. Análisis Legal En Materia de Titularidad de Las Emisiones Reduciads En México; Documento de Trabajo; UN REDD: Rome, Italy, 2018.

62. Karsenty, A.; Vogel, A.; Castell, F. "Carbon Rights", REDD+ and Payments for Environmental Services. Environ. Sci. Policy 2014, 35, 20-29. [CrossRef]

63. USAID. Property Rights and Resource Governance: Democratic Republic de Congo; USAID Country Profiles: Washington, DC, USA, 2010.

64. Government of Mozambique. Constitution of Mozambique of 2004; Maputo, Mozambique, 2004.

65. USAID. Property Rights and Resource Governance: Mozambique; USAID Country Profiles: Washington, DC, USA, 2018.

66. USAID, K. Property Rights and Resource Governance Vietnam; USAID Country Profiles: Washington, DC, USA, 2013; p. 33.

67. Government of Vietnam. Law on Environmental Protection; Vol. No. 55/2014/QH13; Hanoi, Vietnam, 2014.

68. USAID. Property Rights and Resource Governance: Ecuador; USAID Country Profiles: Washington, DC, USA, 2011.

69. USAID. Property Rights and Resource Governance: Madagascar; USAID Country Profiles: Washington, DC, USA, 2019.

70. De Camino Velozo, R.; Villalobos, R.; Morales Aymerich, J.P. Costa Rica Case Study Prepared for FAO as Part of the State of the World's Forests 2016 (SOFO); FAO: Rome, Italy, 2016. 
71. Wallbott, L.; Florian-Rivero, E.M. Forests, Rights and Development in Costa Rica: A Political Ecology Perspective on Indigenous Peoples' Engagement in REDD+. Confl. Secur. 2018, 18, 493-519. [CrossRef]

72. Malavasi, D.E.O.; Kellenberg, D.J. Program of Payments for Ecological Services in Costa Rica. 7; World Bank: Washington, DC, USA, 2002.

73. USAID. Property Rights and Resource Governance: Guatemala; USAID Country Profile: Washington, DC, USA, 2010.

74. USAID. Property Rights and Resource Governance: Peru; USAID Country Profiles: Washington, DC, USA, 2016.

75. Salas, C.; Donoso, P.J.; Vargas, R.; Arriagada, C.A.; Pedraza, R.; Soto, D.P. The Forest Sector in Chile: An Overview and Current Challenges. J. For. 2016, 114, 562-571. [CrossRef]

76. USAID. Property Rights and Resource Governance: Mexico; USAID Country Profiles: Washington, DC, USA, 2017.

77. Dirección General CONAFOR. Letter from the Government of Mexico to the FCPF Management Unit, on File with the Author; Dirección General CONAFOR: Mexico, D.F. Mexico, 2020.

78. NYDF Assessment Partners. Improving Governance to Protect Forests: Empowering People and Communities, Strengthening Laws and Institutions-New York Declaration on Forests Goal 10 Assessment Report; NYDF Progress Assessment; Climate Focus: Washington, DC, USA, 2018.

79. Fetzer, T.; Marden, S. Take What You Can: Property Rights, Contestability and Conflict. Econ. J. 2017, 127, 757-783. [CrossRef]

80. Guardado, J. Land Tenure, Price Shocks, and Insurgency: Evidence from Peru and Colombia. World Dev. 2018, 111, 256-269. [CrossRef]

81. Peters, P.E. Conflicts over Land and Threats to Customary Tenure in Africa. Afr. Aff. 2013, 112, 543-562. [CrossRef]

82. Couillard, V.; Gilbert, J.; Kenrick, J.; Kidd, C. Land Rights and the Forest Peoples of Africa: Historical, Legal and Anthropological Perspectives; Forest Peoples Programme: Moreton-in-Marsh, UK, 2009.

83. Rainforest Alliance. GuateCarbon, Supporting Forest Communities; Rainforest Alliance: New York, NY, USA, 2018.

84. Wemaere, M.; Streck, C.; Chagas, T. Legal Ownership and Nature of Kyoto Units and EU Allowances. In Legal Aspects of Carbon Trading: Kyoto, Copenhagen and beyond; Oxford University Press: Oxford, UK, 2009; pp. 35-58.

85. Streck, C.; von Unger, M. Creating, Regulating and Allocating Rights to Offset and Pollute: Carbon Rights in Practice. CCLR 2016, 2016, 178-189. [CrossRef]

86. Government of Australia. Select Legislative Instrument No. 268, 2011, Made under the Carbon Credits (Carbon Farming Initiative) Act 2011, Compilation Date 4 April 2020; Canberra, Australia, 2020.

87. Soares-Filho, B.; Rajão, R.; Merry, F.; Rodrigues, H.; Davis, J.; Lima, L.; Macedo, M.; Coe, M.; Carneiro, A.; Santiago, L. Brazil's Market for Trading Forest Certificates. PLoS ONE 2016, 11, e0152311. [CrossRef]

88. Freitas, F.L.M.; Englund, O.; Sparovek, G.; Berndes, G.; Guidotti, V.; Pinto, L.F.G.; Mörtberg, U. Who Owns the Brazilian Carbon? Glob. Chang. Biol. 2018, 24, 2129-2142. [CrossRef]

89. Zahar, A.; Peel, J.; Godden, L. Australian Climate Law in Global Context; Cambridge University Press: Cambridge, UK, 2013; p. 348.

90. Overman, H.; Cummings, A.R.; Luzar, J.B.; Fragoso, J.M.V. National REDD+ Outcompetes Gold and Logging: The Potential of Cleaning Profit Chains. PeerJ Prepr. 2018. [CrossRef]

(C) 2020 by the author. Licensee MDPI, Basel, Switzerland. This article is an open access article distributed under the terms and conditions of the Creative Commons Attribution (CC BY) license (http://creativecommons.org/licenses/by/4.0/). 